\title{
COMPLEMENT FIXATION TESTS IN PERTUSSIS
}

\author{
By MANFRED WEICHSEL AND HAROLD S. DOUGLAS \\ (From the Research Laboratories of the Department of Health and the Department of Bac- \\ teriology of New York University; Kingston Avenue Hospital for Contagious \\ Diseases, Brooklyn; and Beth Israel Hospital, New York City)
}

(Received for publication August 17, 1936)

Bordet and Gengou (1), in 1906, performed serological tests on pertussis employing the organisms which they discovered and claimed to be the causative agent of whooping cough as the antigen for the complement fixation test. They got a positive reaction in most cases of the disease. Yet, later investigations failed to confirm these results.

Among those who confirmed their results were Renaux (2) who examined 73 cases, Chievietz and Meyer (3) with 112 cases and Giese (4) with 123 cases. In recent years good results were reported particularly by German authors who employed a method which will be described later. Keller, Klopstock and Klopstock (5) examined 131 sera of 88 cases with pertussis; 77 sera showed a positive reaction, 17 were doubtful, and 37 sera were negative. Gundel and Schlüter $(6,7)$ reported a study of 70 pertussis patients; 54 of these were positive, 3 doubtful, and 13 negative. In a later series of cases they found that of 140 sera from children with pertussis and suspicious cases, 105 gave a positive reaction. The reason given to explain the negative reactions were, either that the children did not suffer from whooping cough or were too young or too sick to form antibodies.

The method employed by the German authors mentioned above consists in preparing an antigen by using whole pertussis bacilli supended in alcohol to which a small amount of lecithin is added. The addition of lecithin tends to render the result more specific and at the same time to decrease the anticomplementary effect of the antigen. In a recently published paper, Hansing (8), using the same method on the sera of 189 patients, found that 48 per cent were positive, 22 per cent doubtful, and 29 per cent negative.

The failure of many workers to obtain good results with complement fixation in pertussis may be explained by the fact that no method was available to differentiate between pertussis and influenza bacilli. Only recently Povitzki (9) found that Bordet-Gengou bacilli grew well on a definitely acid medium ( $\mathrm{pH}$ 5.0) whereas the Pfeiffer bacillus was inhibited by it. Furthermore, Gundel and Schlüter (10) found that genuine pertussis bacilli when injected intradermally into white rabbits always produced severe necrosis while influenza bacilli only caused infiltration and erythema.

Because, in the past, there was uncertainty regarding the differentiation of both organisms the proper antigen was not always employed for the complement fixation test. The agglutination method, on the other hand, did not prove successful owing to the insufficient amount of antibodies during the natural disease. Besides, spontaneous agglutination is often observed and nonspecific results thus obtained. If it could be shown that the complement fixation test becomes positive in pertussis and also follows the injections of bacillus pertussis, this would seem to be another point in favor of the Bordet-Gengou bacillus as the etiological factor in whooping cough. ${ }^{1}$

The problems studied were the specificity of the reaction, its value in the diagnosis of whooping cough, its occurrence during the disease and the duration of the antibody content.

\section{METHOD}

The complement fixation test was carried out in the manner employed by Dr. Thomson of this laboratory for

1 MacDonald and MacDonald (17) produced experimental whooping cough in two humans and protected two others by prophylactic injections of Sauer's vaccine. All four children developed a positive complement fixation test while two non-immunes were negative.

Sauer and Hambrecht (12) injected B. pertussis into the larynx of five healthy young monkeys and observed spontaneous paroxysmal cough after a period of incubation of from one to three weeks.

Rich et al. (13) produced experimental whooping cough in apes. They found that the complement fixation test became positive during the period of cough. 
the complement fixation test for gonorrhea. A test with a total volume of $0.5 \mathrm{cc}$. in each tube was used, the various dilutions of the reagents being added in quantities of 0.1 cc. A 5 per cent suspension of red sheep cells, sensitized with 4 units of hemolytic amboceptor, was employed. In all tests 2 units of complement were used. The sera were diluted 1:5 and inactivated for one-half hour at $56^{\circ} \mathrm{C}$. Serum and antigen controls were included in all tests. The reagents were titrated in the customary way. The time of fixation was 40 minutes in the water bath at $37^{\circ} \mathrm{C}$. Twenty-five minutes after adding the sensitized cells all test tubes were centrifuged and final readings taken. The antigens were tested against positive antisera prepared by injecting rabbits intravenously with increasing amounts of heat-killed or live pertussis bacilli. Three antigens were used during this study. All sera were examined with Antigen A while Antigen $B$ and $C$ were employed in the latter part of our investigation only. The antigens were prepared from 3 different strains, 1 , an old stock strain grown on chocolate agar; 2 , an old stock strain grown continuously for several years on Bordet agar by Dr. Povitzki, and 3, a strain recently isolated by Miss Mishulow of this laboratory. It may be stated here that these three strains apparently belong to one type-Type $B$ of the classification of Krumwiede, Mishulow and Oldenbusch (14), since most sera reacting positively with antigens prepared from one of the three strains also gave fixation with antigens derived from the other strains. There were, however, occasional discrepancies, which could be accounted for by quantitative differences in the antigens, due to the method of preparation.

The pertussis bacilli of Strain 1 were grown on three different media.

1. Chocolate agar, prepared by adding about 15 per cent defibrinated horse blood to veal agar, $\mathrm{pH} 7.4$, heating the mixture gradually up to $70^{\circ} \mathrm{C}$. and pouring plates at this temperature.

2. Blood veal infusion agar, prepared by adding 30 per cent defibrinated horse blood to veal infusion agar $(\mathrm{pH}$ 7.4).

3. Unadjusted Bordet medium, pH 5.8 to 6.1 , which was used as 3 per cent agar and to which 30 per cent defibrinated horse blood was added.

No great differences in the antigenicity of Strain 1 were observed in complement fixation tests while growing the organisms on any of the three media, though the authors found that the antigen grown on 30 per cent horse blood veal infusion agar was especially suitable. The two other strains employed in this work were grown on Bordet agar only.

\section{Antigen preparation}

$A$. Cultures of pertussis bacilli were grown on one of the media described above. After 48 to 72 hours incubation at $37^{\circ} \mathrm{C}$., the growth was washed off with a small amount of sterile physiological salt solution ( 0.85 per cent) and centrifuged for an hour in graduated centrifuge tubes at 3,000 r.p.m. This suspension was mixed with 50 per cent alcohol in the proportion of $1 \mathrm{cc}$. of centrifuged organisms to $200 \mathrm{cc}$. of 50 per cent alcohol. Thus the supernatant fluid was retained in the above mixture. The bacilli were shaken vigorously for about 20 minutes, using glass beads to break them up and then filtered through glass wool. Thus, a homogeneous suspension was obtained. Various amounts of 1 per cent lecithin were added to this stock antigen and tested in preliminary tests. After evaporating the alcohol in an evaporating dish, the bacilli were suspended in an amount of saline solution corresponding to the original volume. For instance, $1 \mathrm{cc}$. antigen was placed in an evaporating dish and, after evaporating the alcohol, was resuspended in 1 cc. of 0.85 per cent salt solution. The saline was added drop by drop and the rounded end of a test tube was used for bringing the dried material into suspension. In most experiments, an antigen dilution of $1: 10$ or 1:15 was found suitable for performing the test. In some positive cases the antigens were further diluted $1: 20,30,40 \ldots$ In using serum from an immunized rabbit or a strongly positive serum of a patient with whooping cough, one can determine the best dilution of the antigen to be used.

$B$. This method is similar to that employed by McNeil (18) for the preparation of gonococcus antigen. The 48 hours growth on unadjusted Bordet agar was scraped and put into about 10 times its volume of absolute alcohol. After mixing, it was centrifuged for 10 minutes, the alcohol poured off, fresh alcohol added, put into a water bath and stirred intermittently for 30 minutes at $56^{\circ}$ C. The alcohol was poured off, ether added, the mixture stirred intermittently for 30 minutes at room temperature, and then the tubes put into the ice box to settle for 15 minutes. The supernatant fluid was pipetted off, and the tubes centrifuged at the lowest speed for 2 minutes with centrifuge lid open. The rest of the ether was poured off, the tubes returned to the ice box, and covered with a light sterile plug to dry. When thoroughly dried, the material was pulverized and weighed. One gram dried powder was diluted in $200 \mathrm{cc}$. 0.85 per cent saline. The solution was then heated for 1 hour at $60^{\circ} \mathrm{C}$.

The antigen thus prepared was used by the authors in the first series of experiments in the following way: The antigens were diluted $1: 15$ to $1: 20$, heated for one-half hour at $56^{\circ} \mathrm{C}$. and centrifuged for 10 minutes at low speed to remove coarse particles. In later experiments, however, the antigen was centrifuged at high speed for 40 to 50 minutes and a translucent fluid was obtained which contained the soluble proteins of bacillus pertussis. This fluid was used undiluted in some tests (corresponding to an original dilution $1: 200$ ) and in dilution of $1: 2$ or $1: 3$ in others. The authors found that treating the fluid with $\mathrm{N} / 20 \mathrm{HCl}$ removed a considerable amount of protein, for after centrifuging, the clear supernatant fluid, on being neutralized with $\mathrm{N} / 20 \mathrm{NaOH}$, exhibited no antigenic effect.

C. Another method for preparing the antigen was: The 48 to 72 hours' growth of pertussis bacilli on Bordet agar 
was washed off into sterile salt solution ( 0.85 per cent) using 2 cc. per plate. After the organisms were broken up by vigorous shaking, the suspension was heated for one hour at $60^{\circ} \mathrm{C}$., and then centrifuged for 40 to 50 minutes. The slightly opaque supernatant fluid was used as an antigen. While the potency of this antigen was not always as high as that of Antigen $A$, the specificity was good. This antigen was stored in the ice box and heated for a short time at $56^{\circ} \mathrm{C}$. before each test.

\section{Ice fixation experiments}

Gundel $(10,11)$ repeatedly mentions the fact that fixation at $0^{\circ} \mathrm{C}$. as compared with that at $37^{\circ} \mathrm{C}$. shows more definitely the specificity of a complement fixation test. Sachs, Klopstock, and Takenomata (15) originally found that unspecific reactions disappear after, 1 , heating the serum to $60^{\circ}$ to $62^{\circ} \mathrm{C}$. or, 2 , on performing the tests in the cold $\left(0^{\circ}\right)$. The authors obtained the best results when they incubated the complement fixation tubes at $7^{\circ}$ to $8^{\circ} \mathrm{C}$. for 3 hours. Experiments with $0^{\circ}$ temperatures did not prove as successful as those reported by Gundel. These experiments were made using different antigens with a rabbit immune serum, to test the specificity while varying the incubation period at $0^{\circ}$. There was fixation at $0^{\circ} \mathrm{C}$. after 1 hour but the titer was considerably lower than at $37^{\circ} \mathrm{C}$. Prolonged incubation for 3 or more hours at $0^{\circ} \mathrm{C}$. did not elicit better results inasmuch as the antigen often became anticomplementary. It may be stated that there was a group of several sera, positive at $37^{\circ} \mathrm{C}$. and only slightly so at $7^{\circ}$ to $8^{\circ} \mathrm{C}$. (incubation period 3 hours). Other sera showed almost identical results as compared with the results in the water bath. Whether the reaction in this first group was specific or not could be determined by absorption experiments only.

\section{Absorption experiments}

Good results were obtained using the following method: A heavy suspension of pertussis bacilli was prepared by scraping the growth of 1 or 2 plates into $1 \mathrm{cc}$ saline. To $0.1 \mathrm{cc}$. serum, $0.35 \mathrm{cc}$. saline and $0.05 \mathrm{cc}$. of the suspension of organisms were added. After mixing the bacilli with the serum dilution, the tubes were incubated at $37^{\circ} \mathrm{C}$. for 30 to 40 minutes, centrifuged for one-half hour at high speed, and the supernatant fluid, representing a $1: 5$ dilution of the serum, was inactivated for 30 minutes at $56^{\circ} \mathrm{C}$. and used.

The question now to be considered is the value of the method in the diagnosis of whooping cough.

Table I gives a survey of all cases of whooping cough examined. As may be seen, some of the children were examined several times. All of these, except one, showed a definite increase in the titer of complement binding antibodies.

Among the 89 cases there were 14 infants. The sera of four of them were positive, one doubt-
TABLE I

Survey of 100 tests performed on 89 children suffering from whooping cough

\begin{tabular}{c|c|c|c|c|c|c}
\hline \hline & \multirow{2}{*}{$\begin{array}{c}\text { Number } \\
\text { of cases }\end{array}$} & \multicolumn{3}{|c}{ Result of complement fixation test } \\
\cline { 3 - 6 } & & 0 & + & ++ & +++ & ++++ \\
\hline years & & & & & & \\
0 to $1 \ldots \ldots$ & 14 & 9 & 1 & 1 & 2 & 2 \\
1 to $2 \ldots \ldots$ & 20 & 4 & 5 & 3 & 5 & 6 \\
2 to $3 \ldots \ldots$ & 16 & 3 & 4 & 3 & 3 & 5 \\
3 to $4 \ldots \ldots$ & 9 & 3 & & & 2 & 5 \\
4 to $5 \ldots \ldots$ & 5 & 1 & & & 1 & 3 \\
5 to $6 \ldots \ldots$ & 8 & 2 & & 1 & 2 & 3 \\
Older....... & 17 & 2 & & 4 & 6 & 9 \\
\hline Totals...... & 89 & 24 & 10 & 12 & 21 & 33 \\
\hline
\end{tabular}

ful, and the others negative. These findings confirm Gundel's observation that infants rarely form antibodies against pertussis bacilli during the disease. Some of the cases had been coughing for weeks when examined by us, and yet showed a completely negative reaction. On the sera of 75 children 1 year and older, 85 tests were performed which are tabulated in Table II.

TABLE II

Survey of 85 tests performed on 75 children of more than one year of age suffering from whooping cough

\begin{tabular}{|c|c|c|c|c|c|}
\hline \multirow{2}{*}{$\begin{array}{l}\text { Duration of } \\
\text { cough }\end{array}$} & \multicolumn{5}{|c|}{ Result of complement fixation test } \\
\hline & $\mathbf{0}$ & + & ++ & +++ & $+++t$ \\
\hline $\begin{array}{c}\text { weeks } \\
1 \\
1 \frac{1}{2} \\
2 \\
2 \frac{1}{2} \\
3 \\
4 \\
5 \\
6 \\
7 \\
8 \\
13\end{array}$ & $\begin{array}{l}3 \\
1 \\
3 \\
2 \\
1 \\
4 \\
1\end{array}$ & $\begin{array}{l}1 \\
1 \\
\\
1 \\
1 \\
1 \\
1 \\
1\end{array}$ & $\begin{array}{l}1 \\
1 \\
1 \\
2 \\
4 \\
3\end{array}$ & $\begin{array}{l}3 \\
1 \\
3 \\
3 \\
1 \\
2 \\
2 \\
1 \\
1\end{array}$ & $\begin{array}{r}4 \\
11 \\
5 \\
1 \\
3 \\
2 \\
3 \\
3\end{array}$ \\
\hline Totals & 16 & 7 & 13 & 17 & 32 \\
\hline
\end{tabular}

Regarding the 16 negative results, one must bear in mind the fact that 7 of these tests were performed during the first two weeks of the disease. After the third week of the cough only 6 tests were definitely negative. There were 69 children older than 1 year who were at least in the second week of the cough. From these patients we obtained 53 positive, 5 doubtful, and 11 negative tests. 
Considering all the single tests performed on children older than 1 year, the authors found 62 positive, 7 doubtful and 16 negative results. Among the negative and doubtful results there were numerous sera from children coughing but 2 weeks or less. Thus we find 73 per cent positive results among all sera of children older than 1 year, regardless of duration of cough. In all sera examined-including those of infants-the result was positive in 66 per cent only. Among the single specimens examined of children of 1 year of age or older with a cough of more than 2 weeks' duration, about 80 per cent showed a positive complement fixation test. For diagnostic purposes, the test has a limited value because after 2 weeks of cough the clinical and hematological findings are usually sufficient to establish the diagnosis. There were, however, a few cases where the diagnosis could be made very early.

In some children, we tried to compare the serological finding with the clinical severity of the disease, in order to determine whether it has any prognostic significance. Only in a very limited number of cases could definite prognostic conclusions be drawn from the result of the complement fixation test. Severe cases with pneumonia and even fatal cases reacted negatively. Since these patients were infants, this result is not surprising. In other severe cases of pneumonia, the reaction was positive early. A more comprehensive study on a larger number of older infants, who are more likely to form antibodies, might possibly clear up this question.

On the occasion of a small epidemic of whooping cough in a children's home, it was possible to examine the blood of 8 children vaccinated with various whooping cough vaccines a short time previously, and that of 3 control children of the same institution. The 8 children (Cases 1 to 8 of Table III) had been coughing at the time of our examination for about $2 \frac{1}{2}$ to 3 weeks only. All of them had been vaccinated about three months prior to the disease.

As may be seen from Table III, the blood of at least 7 of the vaccinated patients showed a considerable titer of complement fixing antibodies in spite of the short persistence of the cough. It is likely that the results have been influenced by the previous vaccination. Since a series of injections given to those children had been finished about 3
TABLE III

Results of complement fixation test in children with whooping cough who had been previously vaccinated

\begin{tabular}{|c|c|c|c|}
\hline $\begin{array}{c}\text { Case } \\
\text { number }\end{array}$ & Age & $\begin{array}{l}\text { Duration } \\
\text { of cough }\end{array}$ & Result \\
\hline $\begin{array}{l}1 \\
2 \\
3 \\
4 \\
5 \\
6 \\
7 \\
8\end{array}$ & $\begin{array}{c}\text { years } \\
4 \\
3 \\
1 \frac{1}{2} \\
2 \frac{1}{2} \\
2 \\
14 \text { months } \\
2 \\
2 \frac{1}{4}\end{array}$ & $\begin{array}{l}\text { weeks } \\
2 \frac{1}{2} \\
3 \\
2 \frac{1}{2} \\
2 \frac{1}{2} \\
2 \frac{1}{2} \\
2 \frac{1}{2} \\
2 \frac{1}{2} \\
2 \frac{1}{2}\end{array}$ & \\
\hline \multicolumn{4}{|c|}{ Controls } \\
\hline $\begin{array}{l}1 \\
2 \\
3\end{array}$ & $\begin{array}{l}2 \\
2 \\
3\end{array}$ & $\begin{array}{l}3 \\
3 \frac{1}{2} \\
3\end{array}$ & $\begin{array}{c}t+ \\
+t+\end{array}$ \\
\hline
\end{tabular}

months before the blood was examined, it is not likely that these children would have shown a positive complement fixation test at the outbreak of the epidemic. As will be demonstrated in another paper, the titers of most patients examined following the vaccination show a definite decline 3 to 4 weeks after the last injection and in several children are completely negative 5 to 6 weeks following the last injection of the whooping cough vaccine. It seems more likely that the antibody response in the group of children mentioned above represents a form of secondary stimulus in a previously vaccinated individual. The 3 control cases do not justify any final statements as to the antibody response in unvaccinated children (with regard to this epidemic), since their number is too small. It is noteworthy, however, that 2 of these 3 children had a definitely lower titer of complement fixing antibodies as compared with the vaccinated patients.

An attempt was made on several occasions to establish the duration of the positive serological findings following the end of the whooping cough period. Since, however, most of the ward patients left the hospital 4 to 8 weeks after the beginning of the disease and failed to reappear in the clinic for bleedings, several months later, the number of cases available to settle this question was insufficient. Therefore, we examined children with various diseases whose history revealed a pertussis a short time previously. Table IV gives a survey of the results of the complement fixation tests on these patients. 
TABLE IV

Result of complement fixation tests in children with a positive history of whooping cough

\begin{tabular}{|c|c|c|c|c|}
\hline $\begin{array}{c}\text { Case } \\
\text { number }\end{array}$ & Age & $\begin{array}{l}\text { Time elapsed } \\
\text { since whooping } \\
\text { cough }\end{array}$ & Disease & Result \\
\hline $\begin{array}{r}1 \\
2 \\
3 \\
4 \\
5 \\
6 \\
7 \\
8 \\
9 \\
10 \\
11 \\
12 \\
13 \\
14 \\
15 \\
16 \\
17 \\
18\end{array}$ & $\begin{array}{c}\text { years } \\
7 \\
7 \\
4 \\
5 \\
6 \\
7 \\
8 \\
11 \frac{1}{2} \\
2 \\
7 \\
7 \\
7 \\
5 \\
7 \\
4 \\
6 \frac{1}{2} \\
4 \frac{1}{2} \\
6\end{array}$ & \begin{tabular}{|rl}
3 & months \\
2 & months \\
$2-3$ & months \\
$2-3$ & months \\
$2-3$ & months \\
$?$ & \\
1 & year \\
$8-10$ & months \\
1 & year \\
$2-3$ & years \\
$1-2$ & years \\
2 & years \\
$2-3$ & years \\
$2-3$ & years \\
$2-3$ & years \\
2 & years \\
3 & years \\
5 & years
\end{tabular} & $\begin{array}{l}\text { Parotitis } \\
\text { Scarlet fever } \\
\text { Scarlet fever } \\
\text { Measles }\end{array}$ & $\begin{array}{c}++ \\
0 \\
0 \\
0^{+} \\
0 \\
0^{+} \\
0 \\
++\end{array}$ \\
\hline
\end{tabular}

Judging from these observations, the reaction seems to remain positive for about 5 to 8 months after the actual disease. The blood of these children with a history of pertussis several years before ordinarily failed to show fixation. It is not certain whether the positive findings on some of the children (as Case 6 of Table IV, where the exact time interval elapsed since the pertussis is not known, or as Case 17 and 18, where the children had suffered from the disease several years before), were actually caused by the whooping cough. The explanation for the positive findings in these cases may be analogous to that given for the adult cases described below.

Besides the cases represented in Table IV, the authors were able to examine the sera from normal children as well as those from children with various diseases with regard to, 1 , previous whooping cough infection, and 2 , the specificity of the complement fixation test in children. In cases of measles, the blood was taken during the first 3 to 4 days after the rash appeared, in scarlet fever-usually during the first two weeks of the illness, in tuberculosis-during different stages.

From these experiments, it may be seen that in children free from whooping cough, a positive complement fixation test usually occurs for a limited time only, after the end of the disease. However, weakly positive or doubtful results were observed in some cases where there was no history
TABLE $v$

Results of complement fixation tests on children with various diseases

\begin{tabular}{c|c|c|c|c|c}
\hline \hline Result & Measles & $\begin{array}{c}\text { Scar- } \\
\text { let } \\
\text { fever }\end{array}$ & $\begin{array}{c}\text { Paro- } \\
\text { titis }\end{array}$ & $\begin{array}{c}\text { Tuber- } \\
\text { culosis }\end{array}$ & Varicellae \\
\hline 0....... & 11 & 38 & 6 & 38 & 6 \\
2 & 1 & $1 *$ & $4^{*}$ (2 cases had per- \\
Poubtful & 2 & 2 & & $\begin{array}{l}\text { cossis 2 to 3 } \\
\text { months before } \\
\text { test) }\end{array}$ \\
\hline
\end{tabular}

* Whooping cough in the history.

of pertussis. The various diseases mentioned in Table V, as measles, scarlet fever, chickenpox, tuberculosis, had no influence on the results of the test itself. Nonspecific reactions were of rare occurrence.

Considering the complement fixation tests performed on all children, there was a total of 140 cases, free of pertussis within the last 8 months or not previously immunized. Only 7 of these were positive, 7 doubtful and 126 negative. In other words, 5 per cent were positive and 5 per cent doubtful, irrespective of a history of whooping cough. However, most of these 14 cases had a positive history of pertussis.

It would therefore appear that the complement fixation test in children, if positive, may be used as a diagnostic test. In a number of cases of whooping cough the diagnosis is often difficult, particularly when the patients are seen late in the disease at a time at which the cough plate is likely to be negative and the cough and blood count may not be typical.

An additional advantage of the complement fixation test is the simplicity of the method.

Different results, however, were obtained when we examined the sera of adults. These sera were taken from a number of healthy adults, patients with syphilis, gonorrhea, and various other diseases (as well as sera from volunteers), and also from professional blood donors. The latter group was chosen because it comprises young, healthy men only. Sufficient data as to a history of pertussis during childhood, could not be obtained in all cases.

From Table VI it may be seen that if the ++ results are disregarded, 76 cases out of $562,13.5$ per cent, showed a strongly positive complement fixation. 
TABLE VI

Results of complement fixation tests in healthy adults

\begin{tabular}{c|c|c|c|c|c}
\hline \hline 0 & + & ++ & +++ & ++++ & Total \\
\hline 447 & 8 & 31 & 35 & 41 & 562 \\
\hline
\end{tabular}

This large percentage is rather surprising and cannot be explained on the basis of an amnesic serological reaction due to pertussis during childhood. As has been stated above, the serological reaction remains positive for a limited time only.

Besides, we tried to find whether there was any relationship between a history of pertussis in these adults and a positive complement fixation test. As far as could be ascertained, no such connection existed. Patients with a history of having had pertussis in childhood would show a completely negative reaction, whereas others who denied having had the disease showed complete fixation.

The next question to be answered was: do the sera of these adults with a positive complement fixation test contain specific amboceptors against Bordet-Gengou bacilli or do they give nonspecific reactions? Absorption tests were performed, according to the method described above, on a number of sera. It was found that the specific antibodies were removed after the sera was absorbed with pertussis bacilli suspensions.

When some of the sera were tested against an influenza bacilli fixing reagent, prepared in the same way as is our Antigen A, the results were negative reactions. At the same time, absorption experiments with pertussis and influenza bacilli demonstrated that sera treated with the latter organisms remained unchanged, while those treated with the pertussis bacilli showed a loss in the antibodies. Table VII gives an example of such an absorption experiment.

TABLE VII

Result of complement fixation test with Antigen $A$ after absorption of serum with pertussis and influenza bacilli

\begin{tabular}{c|c|c|c}
\hline \hline $\begin{array}{c}\text { Case } \\
\text { num- } \\
\text { ber }\end{array}$ & Serum unabsorbed & $\begin{array}{c}\text { Ab- } \\
\text { sorbed } \\
\text { with B. } \\
\text { per- } \\
\text { tussis }\end{array}$ & $\begin{array}{c}\text { Absorbed } \\
\text { with } \\
\text { B. influenzae }\end{array}$ \\
\hline 1 & +++++ & 0 & $+++1++++$ \\
2 & ++++ & 0 & ++++ \\
3 & $++1+++$ & 0 & ++ \\
4 & +++ & 0 & +++ \\
5 & +++ & 0 & +++ \\
\hline
\end{tabular}

In other experiments, a positive complement fixation test carried out at low temperature indicated the specific character of the reaction, according to the conclusions of Gundel $(10,11)$ and Sachs (15) and coworkers. The method, as performed by us, confirmed the observation that the sera of normal healthy adults contained specific antibodies against pertussis bacilli. We cannot at present explain this finding. Some of these people may have suffered a short time ago from slight attacks of whooping cough, hardly noticeable clinically. Successive examinations of these adult sera for several months could possibly help to decide this question. In one instance, where it was possible to examine the sera of an individual (a laboratory technician) several times during one year, the complement fixation test did not change.

We examined the sera of about 15 adults (nurses, physicians, technicians) who were frequently exposed to whooping cough. The percentage of positive cases was about the same as in our group of normal adults. Further examinations are necessary to decide the question of the increase of complement fixation test by exposure without the development of pertussis disease.

It is a well known fact that adults may acquire whooping cough. We may assume that some of the adults with a positive complement fixation test suffer from subclinical infections which give rise to antibody formation. In children, the infection probably leads to a manifest disease, and positive complement fixation without any connection with whooping cough is rare.

In examining a larger number of adult sera we had the opportunity of studying the sera of 20 maternity patients. In all cases the blood from the umbilical cord was also tested. Sera from three of the women gave positive reactions. In these 3 instances there was a remarkable conformity of the results, in that the specimens of serum from the umbilical cords exhibited reactions almost identical with those obtained with the blood from the corresponding mother.

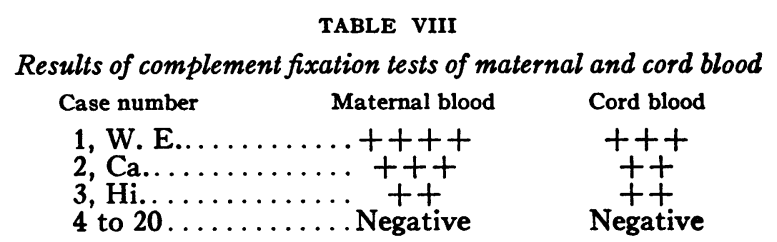


TABLE IX

Antibody response of adults vaccinated with Sauer's vaccine

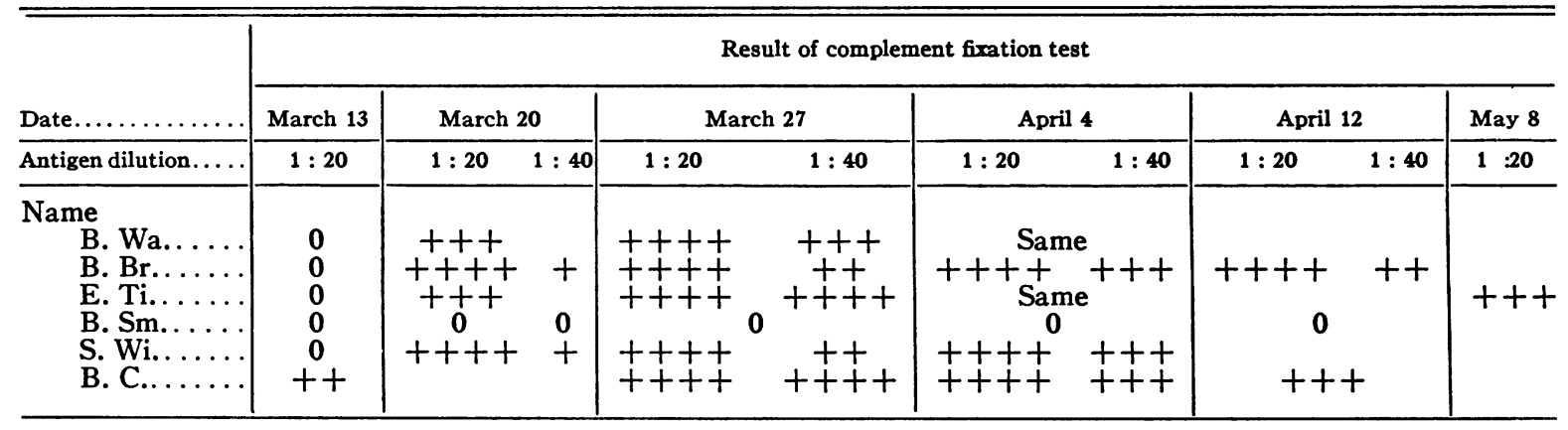

On March 13 and March 20 all patients received 30 billion organisms.

These results seem to indicate that amboceptors against Bordet-Gengou bacilli can pass through the placenta. This fact, as far as we know, has not been observed as yet. In experiments with actively immunized rabbits, C. Bennholdt-Thomsen (16) has shown that antipertussis antibodies can pass the placenta of these animals.

In a number of adults injected with Sauer's vaccine the serological response was studied. Table IX gives a survey of the results in a few patients so treated.

The antibody response in most vaccinated individuals was immediate. The highest titer of antibodies was found 2 to 3 weeks following the last injection. Since it was not possible to follow up all these cases after vaccination, no final conclusion should be drawn. It is remarkable that from a group of 17 patients treated with Sauer's vaccine, 4 failed to show any antibody response, and this, in spite of the fact that they had received 30 billion organisms or 60 billions, depending on whether they got one or two injections.

No difference was observed in the titers and the rate of antibody formation between those adults having had whooping cough in childhood and those with a negative history.

In another paper to be published soon, more data on whooping cough vaccination will be reported.

\section{CONCLUSIONS}

1. The complement fixation test in pertussis, as described in this paper, represents a fairly specific serological test giving positive results in about 80 per cent of the cases with whooping cough above 1 year of age and after the second week of cough.
2. The test in most cases becomes positive towards the end of the second week of the disease and usually remains positive for about 5 to 8 months following the cough.

3. In about 90 per cent of normal children the complement fixation test was negative irrespective of a previous history of pertussis. Five per cent gave doubtful and 5 per cent positive results. Thus the complement fixation test, if positive, is of value, as a diagnostic test in whooping cough.

4. In at least 13 per cent of normal healthy adults, positive reactions were also observed. $\mathrm{Ab}$ sorption experiments and fixation tests at low temperature proved these antibodies to be specific. No relation exists between the findings in normal adults and a positive history of pertussis.

5. In comparable tests with maternal blood and that obtained from umbilical cords, the results suggest that specific antibodies against BordetGengou bacilli passed through the placenta.

6. Some data on vaccination of adults with Sauer's vaccine are given in this paper.

The cases of whooping cough were from the service of Dr. Sylvian Lazarus to whom we are much indebted. We are also indebted to Dr. Spielholz and Dr. Chargin for their very kind cooperation. We further wish to thank Dr. Thomson of the Department of Health Laboratories, for furnishing the reagents for the complement titration and $\mathrm{Mr}$. Koopmann, who supplied most of the adult sera.

\section{BIBLIOGRAPHY}

1. Bordet, J., and Gengou, O., Le microbe de la coqueluche. Ann. Inst. Pasteur, 1906, 20, 731. 
2. Renaux, E., Le microbe de Bordet et Gengou, agent étiologique de la coqueluche. Zentralbl. f. Bakt., 1915, 75, 197.

3. Chievitz, I., and Meyer, A. H., Recherches sur la coqueluche. Ann. Inst. Pasteur, 1916, 30, 503.

4. Giese, H., Recherches sur le bacille de Bordet et son apparition dans la coqueluche. Ann. Inst. Pasteur, 1918, 32, 522.

5. Keller, W., Klopstock, A., and Klopstock, E., Serologische Untersuchungen bei Keuchhusten. Ztschr. f. Kinderh., 1933, 55, 112.

6. Gundel, M., and Schlüter, W., Die Serologie des Keuchhustens. Ztschr. f. Immunitätsforsch. u. exper. Therap., 1934, 81, 218.

7. Gundel, M., Keller, W., and Schlüter, W., Untersuchungen zur serologischen Diagnostik und spezifischen Behandlung des Keuchhustens. Ztschr. f. Kinderh., 1935, 57, 89.

8. Hansing, M. P. I., Untersuchungen über die praktische Brauchbarkeit der serologischen Keuchhustendiagnose. Ztschr. f. Immunitätsforsch. u. exper. Therap., 1935, 86, 449.

9. Povitzki, O. R., Improved methods for the isolation and later cultivation of $B$. pertussis. J. Infect. Dis., 1923, 32, 8.

10. Gundel, M., and Schlüter, W., Experimentelle Unter- suchungen über den Keuchhustenbazillus (Bacillus Bordet-Gengou), seine Diagnose und die Differentialdiagnose gegenüber Influenzabazillen. Zentralbl. f. Bakt., 1933, 129, 461.

11. Gundel, M., Zur Serologie und spezifischen Therapie des Keuchhustens. Deutsche med. Wchnschr., 1934, 60, 744.

12. Sauer, L. W., and Hambrecht, L., Experimental whooping cough. Am. J. Dis. Child., 1929, 37, 732.

13. Rich, A. R., et al., Experiments upon cause of whooping cough. Science, 1932, 76, 330.

14. Krumwiede, C., Mishulow, L., and Oldenbusch, C., The existence of more than one immunologic type of B. pertussis. J. Infect. Dis., 1923, 32, 22.

15. Sachs, H., Klopstock, A., and Takenomata, N., Komplementbindung und Kolloidlabilität. Klin. Wchnschr., 1924, 3, 21.

16. Bennholdt-Thomsen, C., Das Verhalten eines gegen den Bordet-Gengou-Bacillus spezifischen Amboceptors bei Mutter und Kind. Ztschr. f. Kinderh., 1935, 57, 533.

17. MacDonald, H., and MacDonald, E. J., Experimental pertussis. J. Infect. Dis., 1933, 53, 328.

18. McNeil, A., A purified protein antigen for the complement fixation test in gonorrheal infection. Proc. Soc. Exper. Biol. and Med., 1932, 29, 983. 